\title{
UNDERSTANDING THE OBSESSIVE-COMPULSIVE DISORDER: A BOOK REVIEW
}

\section{REVIEW ARTICLE}

VIEIRA, Fernando Filipe Paulos ${ }^{1}$

NETO, Francisco Lotufo ${ }^{2}$

VIEIRA, Fernando Filipe Paulos. NETO, Francisco Lotufo. Understanding the obsessive-compulsive disorder: A book review. Multidisciplinary Scientific Journal Knowledge Nucleus. Year 04, Ed. 10, Vol. 10, pp. 146-154. October 2019. ISSN:24480959

\section{SUMMARY}

The following article has as objective present the principal theories that explain the obsessive-compulsive disorder. These theories includes the biological, psychodynamic, behavioral, cognitive and learning perspectives. Each of these theories enfatizes a specific topic on the development of obsessive-compulsive disorder. Biological perspective enfatizes the functionning of neurotransmitters and structure of the brain in patients with obsessive-compulsive disorder. Psychodynamic perspective enfatizes the developmental experiences that are relationated with the development of obsessions. Behavioral perspective concentres on the behavior that is realized by the patients with obsessive-compulsive disorder that is realized to control anxiety that is provoked by obsessions. Cognitive perspective enfatizes the idea that obsessions are caused by the idea that something must be perfect. Finally, the learning

${ }^{1}$ Mestre em Psicologia Clínica e da Saúde pela Universidade Lusófona do Porto , Graduado em Psicologia Social e do Trabalho pelo Instituto Superior de Ciências Empresariais e do Turismo.

2 Doutorado em Psiquiatria. Especialização - Residência médica. Graduação em Medicina. Graduação em Faculdade de Psicologia PUC-SP.

Disponível em: https://www.nucleodoconhecimento.com.br/uncategorized/obsessive-compulsivedisorder 
perspective enfatizes the idea that compulsions are the result of operant responses that are negativelly reinforced by the relief from anxiety that is provoked by obsessions.

Keywords: obsessive-compulsive disorder, understanding, etiology.

\section{INTRODUCTION}

Obsessive-compulsive disorder is a psychiatric disorder that is characterized by the presence of recurrent obsessions or compulsions that are time-consuming or causes significant distress or interference with normal functionning of an individual (AMERICAN PSYCHIATRIC ASSOCIATION, 2013; PARMET, LYNM, GOLUB, 2011). Obsessions are thoughts, images, ideas, or urges that invade the individual mind, and that cause significant anxiety or distress. Compulsions are repetitive behaviors or mental acts that an individual feel that he or she must to perform to control anxiety caused by obsessions (AMERICAN PSYCHIATRIC ASSOCIATION, 2013).

Some themes characterize thoughts of individuals with obsessive-compulsive disorder (ABRAMOWITZ, MCKAY, TAYLOR, 2008). The theme of obsession most common is dirt or contamination (TOLIN, MEUNIER, 2008). Other common themes are violence and agression, orderliness, religion, and sexuality. The prevalence of these themes vary from culture to culture (MATSUNAGA, SEEDAT, 2011). Religious obsessions are more commom in cultures or countries with strict moral codes and religious values (BJORGVINSSON, HART, 2008).

In general, obsessive-compulsive disorder begins at youth, in males between the six and the fifteen years old and in females between the twenty and the twenty nine years old (ANGST ET AL, 2004, FOA, FRANKLIN, 2001).

Is estimated that between one and three percent of individuals will develop obsessivecompulsive disorder at some time in their lives (KESSLER ET AL, 2005; LECKMAN ET AL, 2010). In the United States, individuals that have origin from Europe have more probability to have obsessive-compulsive disorder than individuals that have origins from Africa (HEWLETT, 2000). 


\section{THE BIOLOGICAL PERSPECTIVE}

Biological perspective of obsessive-compulsive disorder focuses on the idea that obsessive-compulsive disorder may be linked to biological factors (LAMBERT, KINSLEY, 2005). Twins studies suggests that if one identical twin displays obsessivecompulsive disorder, the other can also develops the same disorder. Resumidly, the more similar the gene composes two individuals, the more likely both are to have obsessive-compulsive disorder if one of them have the disorder (COMER, 2013).

In recent years two lines of research have constatated that biological factors play a important role in the development of obsessive-compulsive disorder. This research focuses on abnormal activity of serotonin and the some regions of the brain (COMER, 2013).

Serotonin is a neurotransmitter that transmit messages from neuron to neuron. Clinical researchers found that antidepressants clomipramine and fluoxetine (Anafranil and Prozac), reduce obsessive and compulsive symptoms (STEIN, FINEBERG, 2007). By the fact that these drugs increase serotonin activity, some researchers concluded that obsessive-compulsive disorder could be caused by low serotonin activity. Only antidepressants that increase serotonin activity help individuals with diagnostic of obsessive-compulsive disorder (JENIKE, 1992).

Serotonin is the neurotransmitter most cited in the spoke of obsessive-compulsive disorder, but recent studies suggests that other neurotransmitters like glutamate, GABA, and dopamine may also play an important role in the development of obsessive-compulsive disorder (SPOOREN ET AL, 2010; LAMBERT, KINSLEY, 2005).

Another line of investigation focuses on the abnormal funcionning of specific regions of the brain, in particular the orbitofrontal cortex and the caudate nuclei. These regions are part of a circuit of the brain that converts sensory information in thoughts and actions (CRAIG, CHAMBERLAIN, 2010; STEIN, FINEBERG, 2007). The circuit begins in the orbitofrontal córtex, where sexual, violent, and other primitive impulses arise.

Disponível em: https://www.nucleodoconhecimento.com.br/uncategorized/obsessive-compulsivedisorder 
These impulses move on to the caudate nuclei that act as filters that send the most powerful impulses on to the thalamus, the next stop on the circuit. If the impulses reach the thalamus, the individual is driven to think then about them and perhaps to act. Many theorists believe that orbitofrontal cortex or the caudate nuclei of some individual are too active, leading to a constant eruption of thoughts and actions (ENDRASS ET AL, 2011; LAMBERT, KINSLEY, 2005). Additional parts of the brain circuit have also been identified including the cingulate córtex and the amygdala (STEIN, FINEBERG, 2007).

Investigators found that obsessive-compulsive symptoms do sometimes arise or subside after the orbitofrontal cortex, caudate nuclei or other regions in the circuit are damaged by accident or illness (COETZER, 2004). Brain scan investigations found that the caudate nuclei and the orbitofrontal cortex of individuals with obsessivecompulsive disorder are more active than individuals of control group (CHAMBERLAIN ET AL, 2005; BAXTER ET AL, 2001, 1990). Some research suggests that the abnormalities of serotonin and brain circuits characteristis of obsessive-compulsive disorder are partly the result of genetic inheritance (NICOLINI ET AL, 2011).

\section{THE PSYCHODYNAMIC PERSPECTIVE}

According to psychodynamic theorists anxiety disorders are developed when children fear their own id impulses and use ego defense mechanisms to confront anxiety that is the result of the fear of id impulses. In the obsessive-compulsive disorder the confront between anxiety that provokes id impulses and the anxiety that reduces defense mechanisms develops thoughts and actions (COMER, 2013).

Three ego defense mechanisms are common in obsessive-compulsive disorder: isolation, undoing and reaction formation. Individuals who uses isolation disown their unwanted thoughts and experience them as foreign intrusions. Individuals who uses undoing perform acts that cancel their undesirable impulses. And individuals who uses reaction formation take a lifestyle that confront their unaccepting order to counter unacceptable aggressive impulses (COMER, 2013) 
Sigmund Freud did a relation between obsessive-compulsive disorder anal stage of development. He proposed that during this stage some children experience intense rage and shame as a result of negative training experiences relative to their physiologic needs (ERIKSON, 1963; SULLIVAN, 1953; HORNEY, 1937).

\section{THE BEHAVIORAL PERSPECTIVE}

Behavioral theorists concentres on the explication and treatment of compulsions proposing that individuals perform compulsions quite casualty. When the threat lifts, they link the improvement to that particular action. Individuals with obsessivecompulsive disorder believe that the action give them good luck or can change the situation, and so they perform the same actions again and again in similar situations. The act becomes a method of avoiding feared situations or reducing anxiety provoked by obsessional thoughts (FROST, STEKETEE, 2001).

\section{THE COGNITIVE AND LEARNING PERSPECTIVE}

Individuals with the diagnostic of obsessive-compulsive disorder tend to be concentrated on thoughts (TAYLOR, JANG, 2011). They cannot stop the mental loop in that the intrusive thoughts reverbarates in their minds. They also tend to exaggerate the risk of unfortunate events that can occur. By the fact that they expect terrible things, individuals with obsessive-compulsive disorder engage in rituals to prevent them.

Another cognitive theory is the perfectionism or the idea that one must perform flawlessly (MORETZ, MCKAY, 2009; TAYLOR, JANG, 2011).

According to the learining perspective, compulsive behaviors can be considerated as operant responses that are negatively reinforced by relief from anxiety provoked by obsessional thoughts (FRANKLIN ET AL, 2002). 


\section{FINAL CONSIDERATIONS}

The objective of this article was to present the theoretical perspectives on the spoke of understanding obsessive-compulsive disorder. These theoretical perspectives includes biological, psychodynamic, cognitive and learning perspectives and each of them focuses on a research's subject. Biologic perspective focuses on the investigation of abnormal functionning of neurotransmitters and brain structures. Psychodynamic perspective analyse the impact of early developmental experiences on the development of obsessions. Behavioral theorists focuses on the compulsions that are performed to control anxiety caused by obsessional thoughts. Cognitive perspective believe that obsessional thoughts are caused by the belief of perfeccionism or the belief that something must be performed flawlessly. And, learning perspective enfatizes that compulsive behaviors can be viewed as operant responses that are negatively reinforced by relief from anxiety triggered by obsessional thoughts.

\section{REFERENCES}

ABRAMOWITZ JS, MCKAY D, TAYLOR S (Eds.).Obsessive-compulsive disorder: Subtypes and spectrum conditions. Oxford, England: Elsevier; 2008.

AMERICAN PSYCHIATRIC ASSOCIATION. DSM-5: Diagnostic and statistical manual of mental disorders (5th ed.). Washington, DC: Author; 2013.

ANGST J, GAMMA A., ENDRASS J, GOODWIN R, AJDACIC $\vee$, EICH $D$ et al. Obsessive-compulsive severity spectrum in the community: Prevalence, comorbidity, and course. European Archives of Psychiatry and Clinical Neuroscience, 2004;254(3), $156-164$

BAXTER LR Jr, CLARK EC, IQBAL M, ACKERMAN RF. Cortical-subcortical systems in the mediation of obsessivecompulsive disorder: Modeling the brain's mediation of a classic "neurosis." In D. G. Lichter \& J. L. Cummings (Eds.), Frontal-subcortical circuits in psychiatric and neurological disorders (pp. 207-230). NewYork: Guilford Press; 2001

Disponível em: https://www.nucleodoconhecimento.com.br/uncategorized/obsessive-compulsivedisorder 
BAXTER LR, SCHWARTZ JM, GUZE BH, BERGMAN $\mathrm{K}$ et al. PET imaging in obsessive compulsive disorder with and without depression. Symposium: Serotonin and its effects on human behavior (1989, Atlanta, GA). Journal of Clinical Psychiatry, 51(Suppl.), 1990; 61-69.

BJORGVINSSON, T, HART J. Obsessivecompulsive disorder. In M. Hersen \& J. Rosqvist (Eds.), Handbook of psychological assessment, case conceptualization, and treatment, Vol. 1: Adults (pp. 237-262). Hoboken, NJ: John Wiley \& Sons; 2008.

CHAMBERLAIN SR, BLACKWELL AD, FINEBERG NA, ROBBINS TW, SAHAKIAN BJ. The neuropsychology of obsessive compulsive disorder: The importance of failures in cognitive and behavioural inhibition as candidate endopyhenotypic markers. Neuroscience and Biobehavioral Reviews, 2005; 29(3), 399-419.

COEZTER BR. Obsessive-compulsive disorder following brain injury: A review. International Journal of Psychiatry in Medicine, 2004; 34(4), 363-377

COMER R. Abnormal Psychology, 8th edition. New York: Worth Publishers, 2013.

CRAIG KJ, CHAMBERLAIN SR. The neuropsychology of anxiety disorders. In D. J. Stein, E. Hollander, \& B. O. Rothbaum (Eds.), Textbook of anxiety disorders (2nd ed., pp. 87-102). Arlington,VA: American Psychiatric Publishing; 2010.

ENDRASS T, KLOFT L, KAUFMANN C, KAUFMANN N. Approach and avoidance learning in obsessive-compulsive disorder. Depression and Anxiety, 2011;28(2), 166172.

ERIKSON E. Childhood and society. New York: Norton; 1963.

FOA EB, FRANKLIM E. Obsessive-compulsive disorder. In D.H. Barlow (Ed.). Clinical handbook of psychological disorders: A step-by-step treatment manual (3rd ed,. Pp. 209-263). New York: Guilford Press; 2001. 
FRANKLIM ME, ABRAMOWITZ JS, BUX DA Jr, ZOELLNER L., FEENY N C. Cognitive-behavioral therapy with and without medication in the treatment of obsessive- compulsive disorder. Professional Psychology: Research and Practice, 2002; 33, 162-168.

FROST RO, STEKETEE G. Obsessivecompulsive disorder. In H. S. Friedman (Ed.), Specialty articles from the encyclopedia of mental health. San Diego: Academic Press; 2001.

HEWLETT WA. Benzodiazepines in the treatment of obsessive-compulsive disorder. In W. K. Goodman (Ed.), Obsessive-compulsive disorder: Contemporany issues in treatment (pp. 405-429). Mahwash, NJ: Erlbaum; 2000.

HORNEY K. The neurotic personality of our time. New York: Norton; 1937.

JENIKE MA. New developments in treatment of obsessive-compulsive disorder. In A. Tasman \& M. B. Riba (Eds.), Review of psychiatry (Vol. 11). Washington, DC: American Psychiatric Press; 1992.

KESSLER RC, BERGLUND P, DEMLER O, JIN R, MERIKANGAS KR, WALTERS EE. Lifetime prevalence and age-of-onset distributions of DSM-IV disorders in the national comorbidity survey replication. Archives of General Psychiatry, 2005; 62(6), 593-602.

LAMBERT K, KINSLEY CH.Clinical neuroscience:The neurobiological foundations of mental health. New York: Worth Publishers; 2005.

LECKMAN JF, DENYS D, SIMPSON HB, MATAIX-COLS D, HOLLANDER E, SAXENA S, MIGUEL EC, RAUCH SL, GOODMAN WK, PHILLIPS KA, STEIN DS. Obsessivecompulsive disorder: A review of the diagnostic criteria and possible sutypes and dimensional signifiers for DSM-V. Depression and Anxiety, 2010; 27, 507-527.

MATSUNAGA $H$, SEEDAT $S$. Obsessive-compulsive spectrum disorders: Crossnational and ethnic issues. In E. Hollander, J. Zohar, P. J. Sirovatka, \& D. A. Regier (Eds.), Obsessive-compulsive spectrum disorders: Refining the research

Disponível em: https://www.nucleodoconhecimento.com.br/uncategorized/obsessive-compulsivedisorder 
agenda for DSM-V (pp. 205-221). Washington, DC: American Psychiatric Association; 2011.

MORETZ MW, MCKAY D. The role of perfectionism in obsessive-compulsive symptoms: "Not just right" experiences and checking compulsions. Journal of Anxiety Disorders, 2009; 23, 640-644.

NICOLINI H, ARNOLD P, NESTADT G, LANZAGORTA N, KENNEDY JL. Overview of genetics and obsessive-compulsive disorder. In E. Hollander, J. Zohar, P. J. Sirovatka, \& D. A. Regier (Eds.), Obsessive-compulsive spectrum disorders: Refining the research agenda for DSM-V (pp. 141-159). Washington, DC: American Psychiatric Association; 2011.

PARMET S, LYNM C, GOLUB RM. Obsessivecompulsive disorder. Journal of the American Medical Association, 305, 2011.

SPOOREN W, LESAGE A. LAVREYSEN H, GASPARINI F, STECJLER T. Metabotropic glutamate receptors: Their therapeutic potential in anxiety. In M. B. Stein \& T. Steckler (Eds.), Behavioral neurobiology of anxiety and its treatment. Current topics in behavioral neurosciences (pp. 391-413). NewYork: Springer Science + Business Media; 2010.

STEIN DJ, FINEBERG NA. Obsessive-compulsive disorder. Oxford, England: Oxford University Press; 2007.

SULLIVAN HS. The interpersonal theory of psychiatry. New York: Norton; 1953.

TAYLOR S, JANG KL. Biopsychosocial etiology of obsessions and compulsions: An integrated behavioral-genetic and cognitive-behavioral analysis. Journal of Abnormal Psychology, 2011; 120, 174-186.

TOLIN DF, MEUNIER SA. Contamination and decontamination. In J. S. Abramowitz, D. McKay, \& S. Taylor (Eds.), Obsessive-compulsive disorder: Subtypes and spectrum conditions. Oxford, England: Elsevier; 2008. 
Submitted: September, 2019.

Approved: October, 2019.

Disponível em: https://www.nucleodoconhecimento.com.br/uncategorized/obsessive-compulsivedisorder 